Right-wing extremism/radicalism: reconstructing the concept

Elisabeth Carter

Keele University

School of Politics, Philosophy, International Relations and Environment (SPIRE)

Keele University

Staffordshire

ST5 5BG

UK

e.carter@keele.ac.uk 
Right-wing extremism/radicalism: reconstructing the concept

This article reconstructs the concept of right-wing extremism/radicalism. Using Mudde's influential 1995 study as a foundation, it first canvasses the recent academic literature to explore how the concept has been described and defined. It suggests that, despite the frequent warnings that we lack an unequivocal definition of this concept, there is actually a high degree of consensus amongst the definitions put forward by different scholars. However, it argues that the characteristics mentioned in some of the definitions have not been organized meaningfully. It therefore moves on to distinguish between the defining properties of right-wing extremism/radicalism and the accompanying ones, and in so doing it advances a minimal definition of the concept as an ideology that encompasses authoritarianism, anti-democracy, and exclusionary and/or holistic nationalism.

Keywords: extreme right; radical right; definition; authoritarianism; anti-democracy; nationalism. 


\section{Right-wing extremism/radicalism: reconstructing the concept}

Extreme or radical right political parties have attracted considerable scholarly attention since the so-called 'third wave' of development in the early $1980 \mathrm{~s}^{1}{ }^{1}$ There is a constant supply of studies on the topic, be it on the parties' ideologies, programmes or strategies, the reasons for their electoral success (or otherwise), their impact on policy and/or party competition, their access to and fortunes in office, their (changing) voter bases, or the presence of latent support for their policies amongst the general population. ${ }^{2}$ Yet, in spite of this volume of research, nearly every study on these parties seems compelled to open with some mention of the fact that we still lack an unequivocal definition of right-wing extremism/radicalism (whichever term is preferred). Indeed, it has become almost de rigueur to make this point.

Of course, most authors have better things to do than devote half of their article to questions of definitions and, by their moving swiftly on, we have learned much about the phenomenon of right-wing extremism/radicalism, its complexities and its ever-changing nature. What is more, a perfunctory mention of the absence of agreement on definition is quite rational given that a number of scholars have devoted considerable attention to definitional issues and still, so we are told, no consensus emerges. In short, given an apparent lack of success to date, there seems little incentive to embark yet again on what Gerring calls 'the Sisyphean task of legislating a "good" definition'.

But are we in fact over-egging it? That is, to what extent is it still accurate to argue that we lack a generally accepted (or even acceptable) definition of the concept of right-wing extremism/radicalism? Has there not been some growing consensus in this field of study over how to define this concept? If not, then why not? What is it that we continue to disagree about? And how might we move forward in searching for a consensus, if one is even possible?

It is these questions that this article seeks to address. To shed light on the level of (dis)agreement it canvasses the existing literature on such parties to examine how the concept of right-wing extremism/radicalism has been defined. It does this by first using Mudde's influential study of 1995 as a foundation with which to unpack definitions and examine which features have been mentioned most often. ${ }^{4}$ To explore why certain disagreements persist and to suggest how we might overcome these, it then teases out the properties that are essential to the 'ideological core' of right-wing extremism/radicalism. By taking these steps, the article reconstructs the concept of right-wing extremism/radicalism following Sartori's advice to 'first collect a representative set of definitions; second extract their characteristics; and third, construct matrixes that organize such characteristics meaningfully'. ${ }^{5}$

Given these aims, this article is primarily a conceptual piece: its focus is on definitions and on the features included within them. Although in some places it does draw on examples to more clearly explain certain points, it does not offer an empirical examination of the ideologies of individual parties or discuss how and whether they do or do not meet the various definitions of right-wing extremism/radicalism. As such, the article - in its first half - offers a critical review of the existing definitions. Yet, it does not do so with the intention of arbitrating between the definitions in a quest to find the 'best' one. Rather, as just stated, it seeks to strip the definitions back to their components in an effort to explore what (and how much) they have in common, and to identify where disagreements lie. In its second half, the article then focuses on these definitional differences to understand how and why they occur, and, through a systematic examination and interpretation of the definitions' properties, it considers how we might overcome points of contention so as to move towards offering a definition of the concept that just might be more widely accepted.

This article, therefore, is structured in five parts. It begins with a brief reminder of the purpose of definitions. We know that they are central to scientific enquiry, but it is useful to remember why this is, not least because it will help us focus on how definitions may be built and on what makes a definition 'good'. 
Then, it turns its attention to the concept of right-wing extremism/radicalism. It first discusses why rightwing extremism/radicalism is generally considered to be an ideology, and a right-wing one at that, and it then moves on to explore how this concept has been defined to date. Rather than examining each separate definition in turn, the discussion proceeds thematically, on the basis of the features that are mentioned most often. This allows for areas of consensus and issues of disagreement to be highlighted. Having extracted the characteristics of right-wing extremism/radicalism, the fourth section considers how these may be organized meaningfully. It distinguishes between the defining features of the concept and the accompanying properties, and on this basis, it offers a minimal definition of right-wing extremism/radicalism. The article concludes with a consideration of potential criticisms of the arguments put forward.

A final point should be made before proceeding. Since we are concerned with concept reconstruction, our interest lies with the characteristics of right-wing extremism/radicalism (i.e. the concept's intension) and on how these relate to the parties (i.e. the referents, the concept's extension). Therefore, for the moment, our attention is not on which term best designates our concept. It is for this very reason that the article uses the label 'right-wing extremism/radicalism' throughout. Though this is somewhat clumsy, and will no doubt irritate some readers, the goal is to not let our choice of term limit the identification of either the concept's intension or its extension.

\section{The importance of definitions}

Given that research in the field of right-wing extremist/radical political parties has hardly been impeded by definitional differences, it is tempting to argue that there is little need to preoccupy ourselves with trying to find a workable and accepted definition of the concept. However, while muddling-through does have its attractions, the failure to devote time to concept formation and definition invites problems further down the line. ${ }^{6}$ Definitions not only convey meaning, they also specify meaning: they not only tell us what is included in the concept but also what is excluded. As Sartori succinctly puts it: 'to define is, first of all, to assign limits, to delimit'. ${ }^{7}$ So, a definition of right-wing extremism/radicalism not only sets out what it is, but also distinguishes it from what it is not. This is the first step in moving forward with exploration and analysis, and is the essential means for a scientific community to communicate.

Having a definition of our concept is all the more essential if we wish to engage in comparison because without knowing the meaning of our concept we are unable to discern whether what we wish to compare, be it for similarity or difference, is indeed comparable. Given the wealth of comparative studies on parties of the extreme/radical right, we are clearly making the case that these entities are of the same genus. We are claiming that they belong to the same class of objects - that is, that there are more similarities amongst them than there are between them and other entities. But making this case brings us straight back to the need for definitions as it becomes incumbent on us to show how the entities are comparable - i.e. 'comparable with respect to which properties or characteristics'. ${ }^{8}$ Furthermore, if we are proposing that our concept applies to a number of different cases (at different time periods or in different locales), then we must also provide a definition that is not so temporally or culturally bound as to reduce its applicability.

The definition of a concept may start with consideration of its term, its intension, or its extension. ${ }^{9}$ Roberts' examination of 'the " $\mathrm{e}$ " word' (extremism) suggests the first approach, while Backes' analysis of the 'meaning and forms of political extremism' is more in line with the second. ${ }^{10}$ However, much of the research on right-wing extremism/radicalism begins with the third approach, and analyses the parties (i.e. the extension) and seeks, as Mair puts it, to define these 'real-world phenomena ... in more or less precise terms' ${ }^{11}$ Indeed, in noting the difficulties involved in advancing a definition from the concept's intension or term, Billig suggests that 'an alternative strategy for defining the characteristics of the extreme right would be to start with the movements ... and then to attempt to extract their common distinguishing characteristics.'. ${ }^{12}$ 
This inductive approach, however, gives rise to the 'problem of circularity': the parties we select will have a considerable bearing on any definition we advance. ${ }^{13}$ To get round this problem of endogeneity, a number of studies place parties into families on the basis of data that reflect the parties' ideological and/or issue positions - be it Comparative Manifesto Project data or data from expert judgements. ${ }^{14}$ But while this overcomes some issues, this approach still does not avoid extracting definitions and categorizing parties with reference to what they themselves do or say. Furthermore, the practice of letting the data tell us where to draw cut-off points for inclusion or exclusion has been severely criticized as an instance of putting the quantification cart before the conceptualization horse. ${ }^{15}$

Sartori's solution to this problem is to try to advance a minimal definition that includes the defining properties (or characteristics) [of a concept] and excludes the accompanying properties ${ }^{16}$ without pushing so far as to limit our ability to identify the object. ${ }^{17}$ Crucially this approach matches our aim: it allows us to identify the core of the concept of right-wing extremism/radicalism and to delimit it from other concepts (i.e. it sets out what it is, and distinguishes it from what it is not), and hence it enables us to separate the extreme/radical right party family from other party families. The purpose of a minimal definition is therefore to define, not to describe. Description can come later, when we expand the minimal definition by adding properties appropriate to a more limited set of cases. So, as Mair argues, 'each concept requires a core or minimal definition' because 'unless we can agree on the "one", core, or minimal - most abstract meaning' we will struggle to understand why and how more specific meanings of a concept - 'each appropriate to a particular time and place' - are later developed, and we will not be able to compare these different, more specific meanings with one another. ${ }^{18}$

To be sure, this 'classical' approach to concept formation entails a number of assumptions. As Collier and Mahon point out, this approach assumes that concepts are related to each other 'in terms of a taxonomic hierarchy', that they have clear boundaries, and that all the concept's referents share the defining properties of its intension. ${ }^{19}$ In the case of certain concepts, these assumptions are problematic: some concepts cannot be hierarchically ordered, and in some instances not all members of a class share all the concept's defining properties. For some concepts therefore, alternative approaches to concept formation be it via family resemblance, or by the development of radical categories - may be more apt. ${ }^{20}$ In the case of right-wing extremism/radicalism however, the classical, Sartorian approach does seem most appropriate because the properties that make up the concept's intension can be hierarchically ordered, boundaries can be drawn (albeit with care), and all the referents do share the concept's defining features.

We will see that the existing definitions of right-wing extremism/radicalism vary in the extent of their minimality: while some authors provide quite succinct definitions, others define the concept with reference to a greater number of properties. This just goes to underline that, as Sartori has warned, 'minimal definitions are not easy to come by'. ${ }^{21}$ Indeed, as Hainsworth notes, it is far from straightforward 'to provide neat, self-contained and irrefutable models [sic] of extreme rightism which might successfully accommodate or disqualify each concrete example or candidate deemed to belong to this party family'. ${ }^{22}$ Given these challenges, not only must we proceed with care, but, as Collier and Adcock advise, we also need to recognize that we 'should be cautious in claiming to have come up with a definitive interpretation of a concept's meaning, ${ }^{23}$

\section{Defining the extreme/radical right}

Although, as we shall see, there are issues of contention amongst the different definitions of right-wing extremism/radicalism, there are two points on which the vast majority of scholars do agree. Firstly, most concur that the concept of right-wing extremism/radicalism primarily describes an ideology. ${ }^{24}$ Admittedly some authors have argued that a certain political style, behaviour, strategy, organization or electoral base may also characterize the parties ${ }^{25}$, but these traits should be seen as 'secondary' as they are informed by, and thus follow from, ideology. ${ }^{26}$ The primacy of ideology also explains why extreme/radical right parties 
are viewed as belonging to one, distinct party family, which displays ideological coherence and which can be distinguished from other party families. ${ }^{27}$

Second, there is broad agreement in the literature that this ideology is right-wing. At the same time though, there is wide recognition that defining the right is, in itself, a very difficult task. As Eatwell and Ignazi amongst others have illustrated, a number of different styles of thought characterize the right, making it very hard to identify any common core. ${ }^{28}$ That said, many scholars have turned to essentialist categorizations in discussing the extreme/radical right's 'rightness' and have drawn in particular on the work of Bobbio whose central argument is that it is attitudes towards (in)equality that distinguish left from right. ${ }^{29}$ In being more egalitarian, the left strives to reduce social inequalities and seeks to make natural ones less painful. By contrast, the right is more inegalitarian: it believes that most inequalities are natural and so cannot be eradicated, and it does not consider it the state's responsibility to reduce social inequalities. This method of distinguishing between left and right is particularly attractive to scholars of right-wing extremism/radicalism, not only because these parties have lots to say about (in)equality, but also because the traditional left-right economic divide is a rather unhelpful tool for categorizing them given their rather mixed position on economic issues and the fact that they most often treat economics as a secondary concern. ${ }^{30}$

If we can agree that right-wing extremism/radicalism is a right-wing ideology, clearly, the next question that presents itself is: of what is this ideology composed? And this is where Mudde's 1995 study proved so helpful. On the basis of a review of the academic literature he selected 26 definitions and descriptions of right-wing extremism and created an inventory of the features mentioned therein. He found that no fewer than 58 features were mentioned, and that five characteristics - nationalism, racism, xenophobia, antidemocracy, and the strong state - were included in over half the definitions and descriptions.

Taking nothing away from this study, it does now seem time for a new round of stocktaking. For a start, a considerable amount of work that deals with definitions of right-wing extremism/radicalism has been published since 1995, and we would do well to consider it. Secondly, with the dissolution of some parties, the transformation of others, and the arrival of a few newcomers, there have been changes to the membership of the extreme/radical right party family. This turnover and evolution may well have shaped some of the newer definitions of our concept. Lastly, a new review of definitions will allow us to organize the properties of right-wing extremism/radicalism in a meaningful way. While Mudde's study contained an inventory of the features mentioned most often in definitions and descriptions of the concept, it did not differentiate adequately between the defining and the accompanying characteristics of right-wing extremism/radicalism. This, as we have seen, is crucial if we wish to advance a minimal definition of our concept.

\section{Reviewing existing definitions}

Definitions put forward by 15 sets of scholars have been chosen for analysis. These have been selected not because they are representative in any statistical sense, but because they are deemed to be authoritative and influential: they are advanced by leading scholars in the field, and have been used as foundations by many subsequent, empirical studies. ${ }^{31}$ While these definitions do emanate only from works written in English, they are put forward by a range of scholars, many of whom write in other languages, and have knowledge of the debates found in non-English academic circles. Likewise, while most of the definitions considered come from studies that have engaged in analyses of the extreme/radical right in Western Europe, some are found in works that examine the phenomenon in locations further afield. ${ }^{32}$ There is also nothing inherent in any of these definitions that makes them applicable to specific locales only. Similarly, although nearly all the definitions originate from studies that focus exclusively on political parties, they can equally be applied to social movements, or to looser groups or networks of activists. ${ }^{33}$ With the important exceptions of Ignazi's and Betz's definitions, the definitions considered here have been put forward since 1995 - that is, since Mudde's 1995 study. ${ }^{34}$ 
Of course, these definitions are, to an extent, interdependent in as much as later definitions are informed by earlier ones, not least Mudde's. That said, because the task of advancing a definition involves the 'stripping back' of a concept, it is not a given that there will be substantial path dependency. Furthermore, the fact that the definitions come from studies that examine different parties also limits the degree to which they will necessarily draw on each other. This also overcomes the problem of circularity mentioned above. That is, there is much less need to worry about the impact of case selection on our definition if we draw on a range of studies that have examined different cases.

Table 1 lists the definitions selected for examination, and shows which characteristics are included within them. The table is organized on the basis of the five features that Mudde identified as the ones mentioned most often, thereby allowing us to see whether these properties still dominate the definitions. It also draws attention to any other features mentioned in the definitions.

[Table 1 about here]

\section{The strong state}

Mudde conceptualized the strong state as 'a collective noun for sub-features that have to do with a strengthened repressive function of the state' and defined it on the basis of law and order, and militarism. ${ }^{35}$ As Table 1 indicates, although it is the least referred to property of the five that Mudde examined, a number of authors do include elements of this concept in their definitions. Heinisch, for example, argues that an 'important characteristic of the (new) extreme right is its authoritarian conception of the state. The law-and-order doctrine is directed not only against external threats (immigrants and asylum seekers) and criminal elements, but also against its critics and political opponents' ${ }^{36}$ Copsey also makes reference to the desire of national-populist parties 'to restore strong, ultra-nationalist government and reassert traditional values such as law and order, authority, community, work and family'. ${ }^{37}$ Likewise, although specifically dropping his earlier reference to the term 'strong state', more recently Mudde includes authoritarianism in his maximum definition of the populist radical right, describing it 'as the belief in a strictly ordered society, in which infringements of authority are to be punished severely'..$^{38}$ In a similar fashion, Rydgren notes the 'sociocultural authoritarianism' of the parties and their emphasis on 'themes like law and order', Hainsworth points to the parties' 'authoritarian political perspectives', and Skenderovic speaks of the radical right's 'strong belief in the importance of an authoritarian and hierarchical structured order'. ${ }^{39}$

\section{Nationalism}

Nationalism - which Mudde defined as 'a political doctrine that proclaims the congruence of the political unit, the state, and the cultural unit, the nation' - is included in most of the definitions in Table $1 .{ }^{40}$ In comparing 'national-populist' parties to fascist ones, Copsey argues that they offer 'a more moderate (yet still illiberal) form of ethnocentric nationalism' ${ }^{41}$ Similarly, Minkenberg defines 'right-wing radicalism' by drawing on 'the ideological criteria of populist and romantic ultra-nationalism, that is a myth of a homogeneous nation that puts the nation before the individual and his/her civil rights [and that] is characterized by the effort to construct an idea of nation and national belonging by radicalizing ethnic, religious, lingual, other cultural and political criteria of exclusion, to bring about a congruence between the state and the nation, and to condense the idea of nation into an image of extreme collective homogeneity'.$^{42}$ Eatwell also sees this type of nationalism as the core doctrine of 'extreme right' parties. He argues that the parties are united by 'holistic nationalism', which is 'based on an ethnic conception of the nation [and that] stresses conversion, expulsion or worse of the "Other" and the defence of a traditional conception of community'. ${ }^{43}$ In a very similar fashion, in his later work, Mudde identifies nationalism as a key characteristic of the parties, and emphasizes that it is a particular type of nationalism that is relevant one he terms 'nativism'. This 'holds that states should be inhabited exclusively by members of the native 
group ("the nation") and that nonnative elements (persons and ideas) are fundamentally threatening to the homogeneous nation-state'.$^{44}$ Givens provides a less detailed treatment of the parties' nationalism, but she nonetheless emphasizes that 'for all the radical right parties, the preservation of national identity is paramount' as is protection from threats to the homogeneity of the nation. ${ }^{45}$ Schain et al., Rydgren, Hainsworth, and Skenderovic all also point to some form of ethnic (and hence exclusionary) nationalism in their descriptions of the extreme/radical right. ${ }^{46}$

\section{Racism and xenophobia}

Although nationalism, racism and xenophobia are all discrete concepts, policies of exclusionary nationalism and cultural homogeneity often go hand-in-hand with racism and/or xenophobia. Homogeneity is usually advocated on the grounds that there are irreconcilable natural differences between groups of people and that these groups should not mix - i.e. according to a racist doctrine. As Mudde explains, this racism can be of the classical variety, characterized by a 'belief in natural and hereditary differences between races, with the central belief that one race is superior to the others', or of the culturist or new kind, where the emphasis is on incompatibility rather than hierarchy, and on culture rather than race. ${ }^{47}$ Exclusionary programmes are most often promoted because non-natives are seen as posing a threat to the host community - i.e. on the basis of xenophobia, defined by Mudde as 'fear, hate or hostility regarding "foreigners". ${ }^{48}$ It is the interconnectedness of these beliefs that explains why, even if they are not always referred to explicitly, the notions of racism and xenophobia are still included in many descriptions of rightwing extremism/radicalism.

For Heinisch, racism is central to right-wing radicalism. He points to the emphasis that the parties place on 'racial and ethnic categories' and explains that 'the radical right generally represents anti-egalitarian and thus anti-Western positions founded on the belief in the natural (including biological/genetic) inequality of humans'. ${ }^{49}$ Minkenberg also notes the centrality of racism in the ideologies of these parties, although he underlines their shift away from biological racism towards 'new racism', culturism, or 'ethnopluralism'. He contends that 'the New Right emphasizes the incompatibility of cultures and ethnicities and advocates the right of the Europeans to be different and to resist cultural mixing'. This then demands 'a politically enforced segregation of cultures and ethnicities according to geographical criteria, a global apartheid" ${ }^{50}$ Rydgren similarly highlights the way in which the contemporary parties have distanced themselves from biological racism and anti-Semitism and have instead adopted an ethnopluralist doctrine that 'states that in order to preserve the unique national characters of different peoples, they have to be kept separated. Mixing of different ethnicities only leads to cultural extinction'. He adds that 'in this doctrine, culture and ethnicity are deterministic and monolithic ... [y]et, contrary to the traditional conception of racism, the doctrine of ethnopluralism is not hierarchical: different ethnicities are not necessarily superior or inferior, only different and incompatible'. ${ }^{51}$ Betz and Johnson also note the radical right's 'negation of the possibility of ethnically diverse communities living peacefully side by side in the same society'. ${ }^{52}$ Betz, Hainsworth, Schain et al., Copsey, and Skenderovic all also point to the contemporary parties' use of ethnically-based or racist appeals. ${ }^{53}$

For Rydgren, the ethnopluralist doctrine of the contemporary parties is articulated in part through 'ethnonationalist xenophobia'. That is, in shifting from biological racism to ethnopluralism, the parties have been able 'to mobilize xenophobic and racist public opinions without being stigmatized as being racists' ${ }^{54}$ Likewise, Minkenberg explains that 'ethnopluralism is the New Right's countermodel to the concepts of multiculturalism, a modernized strategy against immigration and integration'. ${ }^{55}$ This anti-immigration rhetoric usually centres on the threat that immigrants are perceived to pose. Heinisch explains that the parties view immigrants and asylum seekers as 'external threats', and advocate 'extreme measures in the name of protecting the sanctity of one's own ethnos'. ${ }^{56}$ Similarly, Givens notes that, in the eyes of these parties, 'immigrants are seen as a threat to national identity and the homogeneity of the country' and that strict anti-immigrant stances are thus adopted, which include proposals for strong immigration controls, repatriation, and policies of national preference in employment and social benefits. ${ }^{57}$ And as we have already seen, Mudde also speaks of the parties viewing non-native persons as 'fundamentally threatening 
to the homogenous nation-state' ${ }^{58}$ Xenophobia or hostility towards foreigners is, in fact, the most often mentioned feature in the definitions and descriptions under consideration. With various degrees of explicitness and emphasis, it is included in all but one of them - the exception being Carter's definition (see Table 1). ${ }^{59}$

\section{Anti-democracy}

Some form of anti-democratic sentiment - which Mudde conceptualizes as a combination of anti-pluralism and a rejection of the fundamental equality of the citizen - is found in nearly all the definitions. ${ }^{60}$ Only those by Schain et al. and Givens omit this feature ${ }^{61}$ In all the works that discuss this characteristic, there is broad agreement with Betz's argument that the parties exhibit a 'rejection of the established socio-cultural and socio-political system'. ${ }^{62}$ It is the values inherent in liberal and pluralist democracy and the procedures and institutions that sustain these values that particularly stick in the craw of right-wing extremists/radicals. Indeed, Carter defines right-wing extremism by reference to two elements: 'a rejection of the fundamental values, procedures and institutions of the democratic constitutional state', and 'a rejection of the principle of fundamental human equality'. ${ }^{63}$ Likewise, Minkenberg describes 'right-wing radicalism' as an ideology that is 'directed against liberal and pluralist democracy ... its underlying values of freedom and equality and the related categories of individualism and universalism', and Betz and Johnson argue that these parties promote 'an aggressive discourse that directly aims at weakening and undermining the values and institutional arrangements and procedures central to liberal democracy'. ${ }^{64}$ Similarly, Mudde points to these parties' 'opposition to some key features of liberal democracy, most notably political pluralism and the constitutional protection of minorities' and to their hostility to 'fundamental values of liberal democracy'. ${ }^{65}$

In spite of these comments, many of these authors and others are at pains to emphasize that the contemporary parties of the extreme/radical right do not reject democracy per se. Betz argues that modern 'radical right-wing populist' parties are quite distinct from historical cases of 'right-wing extremism' in that they do not advocate a 'fundamental rejection of the democratic rules of the game, of individual liberty, and of the principle of individual equality and equal rights for all members of the political community'. ${ }^{66}$ Minkenberg also underlines the fact that '[u]nlike the radical right of the 1950s and 1960s, [this new radical right] does not echo the ideas of inter-war fascism and outright rejection of democracy'. ${ }^{67}$ Likewise, in describing the difference between the 'populist radical right' and the 'extreme right', Mudde argues that 'the radical right is (nominally) democratic, even if they oppose some fundamental values of liberal democracy, whereas the extreme right is in essence antidemocratic, opposing the fundamental principle of sovereignty of the people'. ${ }^{68}$ In a similar fashion, Skenderovic maintains that ' $\left.\mathrm{w}\right] \mathrm{hile}$ the radical right embraces ideological traits characteristic of the extreme right's worldview, e.g., nationalism, (neo)racism and xenophobia, it does not share other key ideological features of the extreme right, in particular a total hostility towards liberal democracy and its basic foundations'. ${ }^{69}$ That they do not reject democracy outright also means that, as Copsey notes, the contemporary parties do 'not present a truly revolutionary alternative to the liberal-democratic order' and, that, as Ignazi points out, they 'do not openly advocate a non-democratic institutional setting' ${ }^{70}$ Instead they regularly profess their faith in democracy and do not openly question its legitimacy.

While there is a consensus that the contemporary parties display a complex and sometimes contradictory relationship with democracy, there is less agreement as to whether this renders them 'anti-system', or even 'anti-democratic'. Ignazi explicitly argues they are anti-system by virtue of their attitudes towards individual and social equality, and their suspicion of, or opposition to, institutions and procedures that safeguard political pluralism. Recalling Sartori's broad definition of the anti-system party, Ignazi maintains that 'even if such parties do not openly advocate a non-democratic institutional setting, they nevertheless undermine system legitimacy [and] express antidemocratic values throughout their political discourse'. ${ }^{71}$ He later adds that "extreme right parties ... exhibit an "opposition of principle" through a well-constructed ideology or a rather loose "mentality", which undermines the constitutional rules of the democratic regime' ${ }^{72}$ Carter echoes these points. Drawing on Ignazi's arguments, she contends that 'if "anti-system" is 
taken to mean behaviour or values that undermine the legitimacy of the democratic system, the parties in question are clearly parties that display anti-system tendencies' ${ }^{73}$ Copsey also concludes that '[b]oth fascism and national-populism are anti-systemic' ${ }^{74}$ Similarly, although he does not actually use the term 'anti-system party', in making the point that extreme right parties 'are prone to extremist discourses and positions, that diverge from the values of the political order in which they operate', Hainsworth very much alludes to Sartori's stricter definition of the anti-system party whose 'opposition abides by a belief system that does not share the values of the political order in which it operates'. ${ }^{75}$

By contrast, Schain et al. argue that '[n]one of these parties is now anti-system in the sense of being principled opponents to democratic processes, nor are most anti-regime' ${ }^{76}$ Similarly, Minkenberg questions the practice of '[s]ome authors [who] insist on including anti-system attitudes or opposition to democracy as an essential definitional criterion'. Although not actually ruling out using the concept of the anti-system party, he emphasizes that 'the question of right-wing radicals' relationship towards democracy remains open for empirical testing'. ${ }^{.7}$

\section{Populism and anti-establishment rhetoric}

As Table 1 shows, in addition to including some or all of the five characteristics that appeared in Mudde's shortlist of most commonly mentioned attributes, most of the definitions considered here contain other features too. Most notably, nine of them make reference to populism and/or anti-establishment rhetoric. They emphasize the parties' 'unscrupulous use and instrumentalization of diffuse public sentiments of anxiety and disenchantment ${ }^{\prime 78}$, their dramatization of 'the vulnerability of the nation in times of a real or presumed crisis $^{79}$, and their ability to 'mobilize on political discontent' ${ }^{80}$ In addition, the parties are described as appealing to and speaking for the 'ordinary people', and as being 'against the corrupt and unrepresentative political class' ${ }^{81}$

From this review of more recent definitions of right-wing extremism/radicalism we can conclude four things. First, definitions of this concept have become more parsimonious over the last 20 years. The shopping-list type definitions with which Mudde had to contend seem to be a thing of the past. ${ }^{82}$ Second, the five characteristics that Mudde identified as the most commonly mentioned ones continue to be the most commonly mentioned ones. That is, nationalism, racism, xenophobia, anti-democracy, and some form of authoritarianism (if not 'the strong state') are still the attributes to which authors refer most often. However, given its recurrent and prominent mention, to these five, we must now also add populism and the anti-establishment rhetoric that goes with it. Third and following from the last two points, there also now appears to be more agreement amongst authors as to how we might best define our concept. In other words, contemporary definitions of right-wing extremism/radicalism are fairly similar to each other, while older definitions of the concept varied quite considerably. However - and this is the fourth point - there are limits to this consensus. Most notably, there is still disagreement over whether the contemporary parties are anti-system parties, and/or over whether they should be described as anti-democratic.

\section{Organizing our characteristics meaningfully}

Identifying the features most commonly mentioned in definitions of the extreme/radical right only gets us so far. We also need to reflect on how we might organize these characteristics meaningfully. Above all, this requires us to consider whether all these features are necessary (or defining) properties of our concept, or whether any of them are merely accompanying attributes that should be excluded from a minimal definition. In doing this, we may also examine how the features relate to each other.

Sartori argues that we are likely to approach the task of concept formation in one of two ways: by giving precedence to the empirical usefulness of a concept, or by prioritizing its theoretical fertility. He explains that, if we are striving for a definition of empirical utility, then we will be concerned, above all, with the 
meaning-to-referent link and thus with the concept's 'extensional or denotational adequacy'. ${ }^{83}$ Therefore, if our prime purpose is to identify which parties belong to the extreme/radical right party family (for simple classification purposes or to then engage in further research, for example, into the electoral success, organization, policies or coalition potential of the parties), we will not only want our definition to be parsimonious, but we will also want it to be adequate and to contain enough characteristics to enable us to identify the parties and the boundaries of the party family.

A definition containing all six of the features discussed above - i.e. the strong state or authoritarianism, nationalism, racism, xenophobia, anti-democracy, and populism or anti-establishment rhetoric - is attractive because it is likely to have considerable denotational power, enabling us to identify the parties that can be deemed extreme/radical right and to set the boundaries of the party family. However, there is still a question mark over whether all of these features are defining properties. Indeed, Mudde himself suggests that not all are, since in his analysis of three parties, he concluded that the five features he considered were present in the ideology of only one party - the Austrian National Democratic Party. He argued that the 'call for the strong state' was not present in its entirety in the ideology of the Dutch Centre Party '86 (CP'86), and that the anti-democracy characteristic was absent in the ideologies of both the CP' 86 and the German National Democratic Party (NPD). ${ }^{84}$ If, as Sartori reminds us, 'the defining properties are those that bound the concept extensionally' then, following Mudde's analysis, on the face of it at least, either anti-democracy and 'the strong state' are not defining features of right-wing extremism/radicalism (and only nationalism, racism, and xenophobia are), or the CP'86 and the German NPD are not part of the extreme/radical right party family. ${ }^{85}$

\section{The 'strong state' and authoritarianism}

If the 'strong state' is conceptualized as a combination of a tough stance on law and order and an emphasis on militarism (as it was in Mudde's 1995 article), it is not a defining feature of right-wing extremism/radicalism for the simple reason that militarism is absent from the ideologies of a number of parties commonly deemed to belong to this family. As Mudde himself noted at the time, militarism did not feature in the ideology of the Dutch $\mathrm{CP}^{\prime} 86 .^{86}$ There are other examples too, such as the Danish Progress Party, whose leader famously proposed abolishing the Danish army and replacing it with an answerphone message, declaring 'we surrender', in Russian. ${ }^{87}$ The composite nature of the 'strong state' attribute thus clearly poses problems for its applicability. In addition, as Mudde has recognized in more recent work, the obsolescence of militarism further undermines its relevance. Like some other scholars, Mudde now suggests that 'authoritarianism' is the more appropriate feature, and he conceptualizes this in such a way as to capture the parties' stances on law and order as well as their emphasis on hierarchical authority. ${ }^{88}$

The question that then arises is whether authoritarianism is a feature that all extreme/radical right parties share. But this is tricky to tackle because many of the existing studies on right-wing extremism/radicalism do not fully unpack the concept of authoritarianism. They do point to some specific policies that may be indicators of authoritarianism (such as strong law and order), but they do not really explain what an authoritarian party ideology might consist of. To some extent this is not surprising because the vast academic literature on authoritarianism has not tended to concern itself with ideology. Rather, it has examined authoritarianism either as a regime type, or following Adorno et al.'s famous study, as a personality trait. ${ }^{89}$

In the literature on regimes, authoritarian systems are characterized by limited political pluralism, and by the concentration and centralization of power in the hands of the few. ${ }^{90}$ While this tells us about how these regimes operate, it is not evident how these features might be transposed into an ideology. What is more, as Linz points out, authoritarian political systems are characterized by the absence of 'elaborate and guiding ideology'. ${ }^{91}$ Attempting to extract a description of an authoritarian ideology from the literature on regimes does not get us very far therefore, and so, like Mudde in his later work, we might more fruitfully turn to the socio-psychological accounts of authoritarianism for this task. ${ }^{92}$ 
Since Adorno et al., and following Altemeyer's influential work, we have understood that the authoritarian personality adheres to traditional values, submits to authority and to the social norms that these authorities endorse, and condemns those who violate these norms and values. ${ }^{93}$ For Altemeyer, the 'rightwing authoritarian' is thus characterized by conventionalism, submission, and aggression. Given these are personality traits, these attributes are relatively easy to operationalize at the level of the individual or the group. It is more of a challenge, however, to transpose them into a party ideology. That said, manifestations of conventionalism can be found in policies that safeguard and promote traditional social norms, values, morality, roles and lifestyles. These include the strong stances against abortion that rightwing extremist/radical parties take, their desire to protect traditional, patriarchal family structures (reflected, for example, in policies towards marriage, child care and women's representation), their firm opposition to gay rights, and their positions on other minority (or outgroup) rights, most notably religious ones. Evidence of submission is harder to identify, precisely because the concept refers to an individual trait, but it is nonetheless apparent in the way the parties speak of the values of order, discipline and compliance, and the duty to respect, defer to, and show pride in the authorities and the state. Not only do these attitudes and behaviours go hand in hand with the traditional values just mentioned, but they also underline the parties' organic vision of society - a vision that requires that society's moral fabric and cohesion be upheld and protected through order and discipline as well as by strong, hierarchical leadership. Finally, authoritarian aggression can be observed in moral, social, political and legal punitive measures. These include condemnation of and discrimination towards those who violate the traditional social norms and who threaten society's cohesion, and strict law and order policies, such as calls for longer sentences, the reintroduction of capital punishment, and a significant increase in the number of prison places.

If authoritarian party ideology is conceptualized in this way, then it is indeed a defining feature of rightwing extremism/radicalism because some mix of conventionalism, submission, and aggression is found in the ideologies of all right-wing extremist/radical parties. Of course, precisely because this conceptualization of authoritarianism is a composite one ${ }^{94}$, the exact blend varies from party to party: some right-wing extremist/radical parties are more socially conventionalist than others; some advocate much stricter law and order measures than others. Moreover it is worth noting that authoritarianism it is not the preserve of right-wing extremist/radical parties only. Parties from other families - particularly conservative ones often share some of its attributes, most notably conventionalism. But this does not change the status of this property: because it is found in the ideologies of all right-wing extremist/radical parties it is a defining characteristic of our concept.

\section{Anti-democracy}

As we have seen, anti-democracy has been described and defined in a number of ways. Yet, some consensus exists in that, explicitly or implicitly, most scholars researching the extreme/radical right have pointed to two dimensions of the concept. Drawing on different definitions of democracy, they have distinguished between an opposition to the rules and institutions of the democratic system (i.e. its procedures) on the one hand, and a rejection of the fundamental values and principles of democracy on the other (i.e. its substance). The distinction is heuristically useful, not least because it allows the diversity within the extreme/radical right party family to be illustrated.

However, for it to be valuable in helping us determine whether anti-democracy constitutes a defining property of right-wing extremism/radicalism we need to fully unpack the dimensions, and we also need to consider how each relates to, and interacts with, the other. As such, we can propose that a procedural definition of democracy may incorporate 'fully contested elections with full suffrage and the absence of massive fraud, combined with effective guarantees of civil liberties, including freedom of speech, assembly and association' ${ }^{95}$ And we can suggest that the substance of democracy includes a belief in the value of diversity and hence tolerance of difference (i.e. pluralism), the principle of political equality (i.e. fundamental equality of human beings), and the valuing of, and respect for, civil and political freedoms. ${ }^{96}$ The two dimensions clearly interact and reinforce each other in that the values of democracy shape the 
procedures of the democratic system, and through the rule of law, these values are then institutionalized and safeguarded.

Given this conceptualization of democracy, the argument here is that any opposition to, or rejection or undermining of, the values of democracy, or of the values and the procedures and institutions of democracy renders a party anti-democratic. ${ }^{97}$ And following this, anti-democracy becomes a defining property of extreme/radical right parties because all parties in the family reject or oppose some or all of the values of democracy (pluralism, equality, civil and political freedoms), and some also object to the procedures and institutions of the democratic state.

To be sure, there is diversity in the nature of the parties' anti-democracy. Firstly, and picking up on the point just made, some parties reject both the procedures and the values of democracy, while others reserve their opposition for its values only. For example, as well as showing hostility to the values of democracy, the Spanish Falangistas and Frente Nacional also displayed contempt for parliamentary democracy, political parties, and elections. ${ }^{98}$ Likewise, until the late 1980s, the Italian Social Movement continued to advocate an alternative corporatist regime, which included compulsory trades unions and saw a limited role for political parties. ${ }^{99}$ Most extreme/radical right parties, however, accept the procedures and institutions of democracy, at least publically, and target only its values. Yet, here too, there is variation. Some parties embrace an ideology that reflects a rejection of pluralism and equality, others display contempt for civil and political liberties, and others take objection to both these sets of values. The Dutch CP'86 rejected all these values: it viewed pluralism with suspicion, adhered to classically racist beliefs and held xenophobic attitudes (underlining its rejection of equality), and it talked of the damage that individual liberties would do to the collective. ${ }^{100}$ The German NPD's ideology is not dissimilar. It too shows contempt for individual rights and freedoms, and it too embraces fervent xenophobia and classical racism. ${ }^{101}$ Other parties target only some of these values. For instance, the Swiss Freedom Party takes no issue with the principle of civil and political freedom and instead emphasizes its neo-liberalism and individualism. ${ }^{102}$ However, this party embraces an exclusionary ideology (as manifested by its xenophobia) and a hostility to diversity, thereby showing a rejection of pluralism and equality. By contrast, for the Iberian parties, it was not the principle of equality that was the problem. Indeed, xenophobia and racism did not feature in these parties' belief-systems (see below), and as Casals reminds us with reference to the Spanish parties, their Catholicism carried with it 'an egalitarian and anti-racist political culture' ${ }^{103}$ Rather, it was civil and political rights and freedoms that these parties objected to. But these fascinating differences notwithstanding, the point made above stands: their rejection of the values of democracy, or their rejection of the values and the procedures of democracy, renders all these parties anti-democratic, thereby making anti-democracy a defining feature of right-wing extremism/radicalism.

\section{Nationalism}

While some authors do not discuss whether nationalism should be considered a defining property of rightwing extremism/radicalism, others not only do, but also argue that it is the, or a, core element of the concept. Eatwell is very clear on this and states that the extreme right family of parties does have a common core doctrine. This is nationalism' ${ }^{104}$ Similarly, Minkenberg contends that 'right-wing radicalism is defined as a political ideology, the core element of which is a myth of a homogeneous nation', and Mudde argues that 'nativism clearly constitutes the core of the ideology of the larger party family'. ${ }^{105}$ Rydgren also suggests that nationalism is a defining feature of the concept, though, for him, the 'fundamental core' encompasses 'anti-political establishment populism' as well as 'ethnonationalist xenophobia'. ${ }^{106}$ Likewise, Givens argues that these parties have a number of 'traits in common' and that 'one of [their] main defining characteristics ... is nationalism'. ${ }^{107}$

Given these arguments, we might well wonder why nationalism is not mentioned in all the definitions of right-wing extremism/radicalism we have explored. Of course, we can only read into other people's work so much, but the mention of 'hostility towards foreigners' in Ignazi's definition, of the parties' 'appeal to xenophobia, if not overt racism' by Betz, and the emphasis that Heinisch places on (new) racism all entail 
exclusion, which necessarily pits outgroups against an ingroup. ${ }^{108}$ And for parties of the extreme/radical right, the ingroup is defined by national identity, which, in turn, rests on racial, ethnic, and/or cultural belonging. It is the nation (so conceived) that is to be protected from threats to its identity, values, and resources.

Case studies and comparative works provide ample empirical evidence in support of the argument that nationalism is a defining feature of parties of the extreme/radical right, though there is some variation in the nationalism of these parties. ${ }^{109}$ While most parties seek to safeguard nations that are congruent with current state forms, others are concerned with nations that do not map onto present state boundaries. The focus can be on sub-state units of identity (such as Flanders or Padania) or on pan-state ones (e.g. the German Volk). There are also differences in how the parties conceptualize the nation, and in how they define membership of the national community. Some parties conceive of the nation in unitary terms and hence adhere to a holistic or collectivist nationalism in which the nation takes on independent attributes and which requires the individual to be subservient to the nation's will and goals. For other parties the tie between the nation and its members is less intense, and they place more emphasis on individualism and individual liberties. Similarly, while most extreme/radical right parties define membership of the nation in ethnic terms, and advance policies of exclusion or expulsion for non-members, a smaller number of parties are more open to non-members assimilating into the national community and to being able to acquire membership - i.e. to a more 'civic' conception of membership of the nation. ${ }^{110}$

Some examples are perhaps helpful here. One party whose nationalism can be described as both holistic and exclusionary is the German Republikaner. At the core of the party's nationalism is the belief in the importance of the ethnic community (Volksgemeinschaft), without which the individual cannot fully develop. ${ }^{111}$ The tie between the individual and the nation is thus intense. Moreover, the nation is conceived of in ethnic terms, where membership is inherited rather than acquired. By contrast, the Swiss Freedom Party's nationalism is not of a holistic kind, though it is clearly exclusionary. The party does not talk of individuals' obligations to the nation, or of the nation's will or goals. In fact, as we have seen, it attaches considerable importance to individualism. But it fervently opposes immigration and multiculturalism, which it views as grave threats to the Swiss people, and which it frames in cultural and racial terms. ${ }^{112}$ Different again is the nationalism of the Italian Social Movement (later National Alliance). This was not of an exclusionary variety, not least because the party never pursued anti-immigrant or racist policies. Indeed, at times, it defended the rights of immigrants already settled in Italy. But it certainly was holistic. The party displayed nostalgia for an 'organic national community' that needed 'regenerating' and mobilizing, and in this vision, the individual was clearly subordinate to the nation and its will. ${ }^{113}$

That there is variation in the nationalism of extreme/radical right parties is hardly surprising given that these actors exist in different settings and cultures, and perhaps more than other type of party, draw on different histories and traditions. But what is common to the nationalism of all these parties is that it is anti-democratic. In its holistic form, it undermines the civil and political liberty of the individual through the requirement of subordination to the collective, while when it is exclusionary, not least because it targets minorities who are citizens, it signals a rejection of pluralism, diversity and equality. The communality then, is that all extreme/radical right parties perceive that the homogeneity and unity of the nation is endangered, and their response is an anti-democratic one. This nationalism, be it exclusionary, holistic or both, is thus a defining characteristic of right-wing extremism/radicalism.

\section{Xenophobia and racism}

Although, as was emphasized earlier, nationalism, xenophobia and racism are discrete concepts, the points above underline just how closely related to each other they are. Moreover, they indicate that xenophobia and racism are manifestations of exclusionary nationalism. But does this mean they are also defining features of right-wing extremism/radicalism? 
Even though xenophobia and racism are found in the vast majority of descriptions of right-wing extremism/radicalism, the answer to this question has to be 'no'. As we have just seen, while these features are found in the ideologies of many right-wing extremist/radical parties, there is a small number of parties in this party family that have not mobilized around issues of race and immigration. We have already mentioned the Italian Social Movement / National Alliance whose leadership repeatedly maintained a clear objection to xenophobia, racism and anti-Semitism. ${ }^{114}$ To this party we can add the Spanish Falangistas, as well as Blas Piñar's Fuerza Nueva and Frente Nacional which never campaigned on a platform of antiimmigration and racism. The same was the case for the Portuguese and (most of) the Greek extreme/radical right parties of the late 1970 s and 1980s. All these parties' ideology was rooted in nostalgia for the authoritarian, ultra-conservative regimes of the respective countries, hostility to democracy, fervent anti-Communism, and in the case of the Iberian parties, ultra-Catholicism. ${ }^{115}$

\section{Populism}

Few of the earlier definitions of right-wing extremism/radicalism included populism because, for a long time, it was considered to be primarily a political style rather than an ideology. ${ }^{116}$ More recently, however, a number of scholars have argued that populism is an ideology, even if it is a 'thin-centred' one. ${ }^{117}$ Mudde describes populism as 'an ideology that considers society to be ultimately separated into two homogeneous and antagonistic groups, "the pure people" versus "the corrupt elite", and which argues that politics should be an expression of the volonté générale (general will) of the people'. ${ }^{118} \mathrm{His}$ definition thus emphasizes the fundamental position of 'the people' in populism (i.e. power derives only from the people), the unity of 'the people' (conceived in the singular form), and populism's bipolar conception of society (the people against the elite and outsiders). To this characterization, others have added populism's hostility towards the institutions and procedures of representative democracy, which are seen as promoting individualism, pluralism and elitism, and which, in turn, threaten the organic notion of the people. ${ }^{119}$

As just noted, populism has been described as 'thin-centred' because, unlike other, full ideologies, it has 'a restricted core' and hence has 'limited ideational ambitions and scope'. ${ }^{120}$ Reflecting this conceptualization, Taggart speaks of the 'empty heart' of populism, while Fieschi highlights that 'populism's core concepts cannot stand on their own'. ${ }^{121}$ Populism's thinness is reflected in its lack of a coherent programmatic base or a specific set of policy positions, and, as is evident from the wide variety of forms of populism found around the world, it is open to cohabiting with other, fuller ideologies. ${ }^{122}$

Many studies illustrate how different extreme/radical right parties embrace populism and frame their arguments in terms of its elements. Moreover, since these parties conflate 'the people' with the nation, their populism has been described as a populism of identity or as 'national-populism'.${ }^{123}$ However, not all parties considered to belong to the extreme/radical right family are populist, not least because of their neo-fascist heritage and their undemocratic and elitist character. ${ }^{124}$ In his examination of extreme/radical right parties in 17 countries, Taggart identifies as many non-populists as populists, and Mudde draws up a similar, if rather shorter, list of non-populist extreme/radical right parties. ${ }^{125}$ That populism is absent from the ideology of a number of parties clearly indicates that this feature is not a defining property of rightwing extremism/radicalism. Rather it is a characteristic that describes a sub-set of parties within the wider party family.

\section{A minimal definition}

Having examined the features mentioned most often in existing definitions of right-wing extremism/radicalism, and having organized these properties in a meaningful way, we have argued that authoritarianism, anti-democracy, and an exclusionary and/or a holistic kind of nationalism are defining properties of right-wing extremism/radicalism. By contrast, xenophobia, racism, and populism are accompanying characteristics of the concept. We can therefore propose a minimal definition of right-wing extremism/radicalism as: an ideology that encompasses authoritarianism, anti-democracy, and 
exclusionary and/or holistic nationalism. As well as being confined to the necessary features of the concept, this definition strikes a balance between parsimony and denotational adequacy. ${ }^{126}$ It is not overly long and yet it has empirical usefulness in that it allows us to identify parties that belong to the extreme/radical right family, be they longstanding members, new arrivals, or even possible future additions.

Before concluding it is useful to consider further how the three defining features of right-wing extremism/radicalism relate to each other. We have already noted the link between the parties' nationalism and anti-democracy. That is, the holistic nature of the nationalism of some extreme/radical right parties demands that the individual be subordinate to the will and goals of the nation, thereby undermining and restricting rights and freedoms. The nationalism of other extreme/radical right parties is not of this kind, but is nevertheless also anti-democratic because it is based on an opposition to pluralism and it rejects the principle of equality. In different ways then, all extreme/radical right parties consider that the nation is in danger, and their response to this threat is an anti-democratic one.

As for the relationship between authoritarianism and nationalism, the traditional values (i.e. the conventionalism) that extreme/radical right parties draw on and promote are heavily shaped by their conception of the nation as an organic entity which is to be valourized and safeguarded, and by specific attitudes towards what constitutes membership of the nation. In turn, the protection that the nation requires demands respect, order and discipline (i.e. submission), and threats to the nation, particularly from outgroups that do not conform to the traditional understanding of the national community, should be met with aggression. As such then, the authoritarianism of right-wing extremist/radical parties is driven by their nationalism.

As a general concept, authoritarianism is not necessarily anti-democratic. ${ }^{127}$ But it certainly can be, and in the case of parties of the extreme/radical right, it is. In some instances, the traditional values that the parties advocate are anti-pluralistic, promote inequality, or limit civil and political freedoms. The submission that many parties call for also entails a curtailment of individual rights and liberties. And the aggression towards those who do not conform to these values (reflected in condemnation, discrimination, and punitive measures) exposes a rejection of pluralism, equality, and individual freedoms. Thus, whether it is through their specific conventionalism, their demands for submission, or their aggression, the authoritarianism of extreme/radical right parties is anti-democratic in character.

\section{Conclusion and reflections}

With regard to how the concept of right-wing extremism/radicalism has been defined in the academic literature, it seems that while some things change, others stay the same. We have seen that definitions have become more parsimonious and more similar over the last 20 years, yet we have also noticed that the same characteristics still dominate. Authoritarianism, nationalism, racism, xenophobia, and anti-democracy continue to be the features that are mentioned most often, although to these, we must now add populism. Our review of the definitions also indicates that the debate over whether these parties should be deemed anti-system and/or anti-democratic goes on.

At the outset of this piece, we reminded ourselves of the role of definitions and, following Sartori's guidance, we argued that if we seek a definition that will enable us to 'seize the object' - i.e. that will allow us to identify the core elements of right-wing extremism/radicalism and the parties that belong to this family - then we must confine our defining to the necessary properties of the concept, and exclude the accompanying characteristics. Having observed that most existing definitions of right-wing extremism/radicalism do not heed this advice and do not adequately distinguish between the two types of features, we then reconsidered the properties in turn, in a bid to ascertain the status of each. We argued that while the parties' authoritarianism, their anti-democracy, and their exclusionary and/or holistic nationalism should all be considered defining properties of right-wing extremism/radicalism and should 
thus form the basis of a minimal definition of the concept, xenophobia, racism, and populism are accompanying characteristics.

Of course, a number of criticisms may be levelled against this approach and the resulting minimal definition that stems from it. Firstly, it might be argued that this definition is too limited. Indeed, Zaslove makes this point in relation to Mudde's definitions and maintains that 'the populist radical right ... cannot and should not be reduced to a limited set of core concepts [because this] leads to definitions that are too limited, and in the process important ideological concepts are excluded'. ${ }^{128}$ While the absence of certain frequently occurring characteristics (e.g. xenophobia or racism) in any definition might at first raise an eyebrow, this argument misses the point of a minimal definition. As we have emphasized, the purpose of such a definition is to identify the referents and delimit right-wing extremism/radicalism from other ideologies. It is not to describe.

Secondly, critics may well contend that the minimal definition advanced here overstates the anti-system or anti-democratic element of right-wing extremism/radicalism. ${ }^{129}$ However, the centrality of anti-democracy in the definition is explained with reference to how different properties of right-wing extremism/radicalism relate to each other. As we have seen, the nationalism of the parties (be it exclusionary or holistic, or both) is anti-democratic. Moreover, this nationalism is the driver for the parties' authoritarianism, which is also anti-democratic. This is why anti-democracy assumes such a pre-eminent role in the definition advanced here.

Interestingly, this argument is not only very much in line with Ignazi's conclusions, but it also finds support in Mudde's more recent comments (which seem to have been overlooked by many scholars) that 'the [radical right's] defining feature is natural inequality or hierarchy, not nationalism' ${ }^{130}$ Furthermore, the place of anti-democracy in the definition advanced here reflects the centrality of the feature in Carter's earlier work, where right-wing extremism was defined by two anti-constitutional and anti-democratic features, namely a rejection of the fundamental values, procedures and institutions of the democratic constitutional state, and a rejection of the principle of fundamental human equality. ${ }^{131}$ The present definition improves on this previous one by including all the defining features of the concept (i.e. by incorporating authoritarianism and nationalism as well as anti-democracy), and by therefore having greater denotational adequacy. Yet, it remains very much centred on the parties' attitudes towards the procedures, substance and values of democracy.

Thirdly, readers may object to the definition on the grounds that its conception of democracy is too specific, and that the parties are in fact being judged on their attitudes towards liberal democracy. This point carries weight, as the definition very much rests on a rejection of the values of democracy - in particular of pluralism, equality, and civil and political rights - and there is less emphasis on the procedures of democracy. Moreover, other elements of democracy, such as popular sovereignty - to which (most of) the parties show no opposition - have not been discussed. The response to such criticism is that firstly, and as already touched upon, the attention paid to values is justified by the argument that it is the parties' attitudes towards democracy that shape their views on the procedures of democracy (and not the other way round). As for the second element of the objection, the claim here is that although popular sovereignty is an essential feature of democracy - as it is through popular sovereignty that democracy derives its legitimacy - it is not a sufficient one because the referent here is not 'etymological democracy' but modern democracy. Democracy not only requires that majority rule be limited by minority rights, but modern democracy also safeguards the freedom of the individual and provides effective guarantees of civil liberties against the power of the state. ${ }^{132}$ As Sartori reminds us, while freedom is 'by no means the requisite constituent element of democracy per se', 'in the political sense ... [t] constitutional state'. ${ }^{133}$ As such then, and given too that the parties exist in 'Western-type' systems, evaluating their democratic credentials against the characteristics of these very systems seems appropriate.

By conceptualizing anti-democracy as a rejection or an undermining of the values of (modern) democracy, or of the values and the procedures of (modern) democracy, the intention has been to accommodate the varied and complex attitudes of the parties towards all facets of democracy. In short, the aim has been to 
leave maximum room for inclusion, while at the same time ensuring that this conceptualization still points to a difference of kind $^{134}$ That is, it refers to an anti-systemness that sets right-wing extremist/radical parties apart from their mainstream counterparts. Which parties qualify for inclusion in the extreme/radical right party family then becomes a matter of empirical investigation. Of course, there will be borderline cases. Moreover, some parties are likely to have either moved into this party family (e.g. the Italian Lega Nord or perhaps the Swiss People's Party), or out of it (e.g. the now-defunct Italian National Alliance or the Norwegian Progress Party). ${ }^{135}$ In addition, as time goes by, through new arrivals or through the 'modernization' of existing parties (e.g. the 'dédiabolisation' of the French Front National), we are likely to see an increased preponderance of specific types of right-wing extremist/radical party, namely those that embrace exclusionary rather than holistic nationalism, that do not (openly) reject the procedures of democracy, and that frame their discourse and policies in populist terms. Yet, all this does not mean that our minimal definition becomes redundant. Given the task at hand is to identify the core element of rightwing extremism/radicalism in the so-called 'third wave', the emphasis is on what unites the parties of the extreme/radical right, and what sets them apart from other families. ${ }^{136}$ 
Table 1: Properties included in definitions of right-wing extremism/radicalism

Strong state/ Nationalism Racism Xenophobia Anti-democracy Other
Authoritarianism

\begin{tabular}{|c|c|c|c|c|c|c|}
\hline Ignazi $(1992,2002)$ & $\bullet$ & & & $\bullet$ & $\bullet$ & - \\
\hline Betz (1994) & & & $\bullet$ & $\bullet$ & $\bullet$ & Populism; free market; smaller state \\
\hline Eatwell (2000) & & $\bullet$ & $\bullet$ & $\bullet$ & $\bullet$ & - \\
\hline Minkenberg $(2000,2001,2003)$ & & $\bullet$ & $\bullet$ & $\bullet$ & $\bullet$ & Anti-establishment; populism \\
\hline Schain et al. (2002) & & $\bullet$ & $\bullet$ & $\bullet$ & & Populism \\
\hline Heinisch (2003) & • & & $\bullet$ & $\bullet$ & $\bullet$ & Economic liberalism \\
\hline Betz \& Johnson (2004) & & $\bullet^{\mathrm{a}}$ & $\bullet^{\mathrm{a}}$ & $\bullet$ & $\bullet$ & Populism \\
\hline Carter (2005) & & & & & $\bullet$ & - \\
\hline Givens (2005) & & $\bullet$ & & $\bullet$ & & Anti-establishment \\
\hline Rydgren (2005) & $\bullet^{b}$ & $\bullet$ & $\bullet$ & $\bullet$ & $\bullet$ & Anti-establishment; populism \\
\hline Kitschelt (2007) & & $\cdot{ }^{c}$ & $\bullet^{c}$ & $\cdot{ }^{c}$ & $\cdot{ }^{c}$ & Market-liberal economic position \\
\hline Mudde (2007) & $\bullet$ & $\bullet$ & $\bullet^{d}$ & $\bullet$ & $\bullet$ & Populism \\
\hline Copsey (2008) & $\bullet$ & $\bullet$ & $\bullet$ & $\bullet$ & $\bullet$ & Populism; charismatic leadership \\
\hline Hainsworth (2008) & $\bullet$ & $\bullet$ & $\bullet$ & $\bullet$ & $\bullet$ & - \\
\hline Skenderovic (2009) & $\bullet$ & $\bullet$ & $\bullet$ & $\bullet$ & $\bullet$ & Populism \\
\hline
\end{tabular}

Notes:

${ }^{a}$ Betz and Johnson argue that the radical right seeks 'to transform liberal democracy into an ethnocratic regime, which gives supremacy to the interests of "the people", defined in terms of a narrow conception of citizenship'. ${ }^{1}$

${ }^{b}$ Rydgren considers authoritarianism (which includes an emphasis on law and order and family values) an accompanying characteristic rather than a defining one. ${ }^{2}$

${ }^{c}$ Kitschelt argues 'radical right parties either explicitly reject democracy (regardless of their stance on xenophobia and racism), or they embrace democracy, but make xenophobic mobilisation against immigrants and insistence on a dominant national cultural paradigm obligatory for all residents the central planks of their policies'.3

${ }^{d}$ Mudde explains that nativism demands that non-natives are to be excluded, and that the basis for this exclusion can be ethnic, racial or religious, but will always have a cultural component. ${ }^{4}$ This comes close to a definition of 'new racism' in which groups are distinguished and separated on the basis of culture rather than race.

\footnotetext{
[Notes to be converted into endnotes when table is inserted into main text]

${ }^{1}$ Hans-Georg Betz and Carol Johnson, 'Against the current - Stemming the tide: the nostalgic ideology of the contemporary radical populist right', Journal of Political Ideologies, 9(3) (2004), p. 313.

2 Jens Rydgren, 'Is extreme-right populism contagious? Explaining the emergence of a new party family', European Journal of Political Research, 44(3) (2005), p. 433, note 1.

3 Herbert Kitschelt, 'Growth and persistence of the radical right in postindustrial democracies: advances and challenges in comparative research', West European Politics, 30(5) (2007), p. 1178.

${ }^{4}$ Cas Mudde, Populist Radical Right Parties in Europe (New York: Cambridge University Press, 2007), p. 19.
} 


\section{Notes and references}

${ }^{1}$ Klaus von Beyme, 'Right-wing extremism in post-war Europe', West European Politics, 11(2) (1988), pp. 1-18.

${ }^{2}$ See the really useful bibliography of works on the extreme/radical right compiled by Kai Arzheimer: http://www.kaiarzheimer.com/extreme-right-western-europe-bibliography

3 John Gerring, 'Ideology: a definitional analysis', Political Research Quarterly, 50(4) (1997), p. 964.

${ }^{4}$ Cas Mudde, 'Right-wing extremism analyzed: a comparative analysis of the ideologies of three alleged right-wing extremist parties (NPD, NDP, CP'86)', European Journal of Political Research, 27(2) (1995), pp. 203-224.

${ }^{5}$ Giovanni Sartori, 'Guidelines for concept analysis', in Giovanni Sartori (Ed.) Social Science Concepts: A Systematic Analysis (Beverly Hills CA: Sage, 1984), p. 41.

${ }^{6}$ Peter Mair, 'Concepts and concept formation', in Donatella della Porta and Michael Keating (Eds) Approaches and Methodologies in the Social Sciences: A Pluralist Perspective (Cambridge: Cambridge University Press, 2008), p. 180.

${ }^{7}$ Giovanni Sartori, The Theory of Democracy Revisited (Chatham NJ: Chatham House, 1987), p. 182.

${ }^{8}$ Giovanni Sartori, 'Comparing and miscomparing', Journal of Theoretical Politics, 3(3) (1991), pp. 245-246.

${ }^{9}$ John Gerring, 'What makes a concept good? A critical framework for understanding concept formation in the social sciences', Polity, 31(3) (1999), p. 389.

${ }^{10}$ Geoffrey K. Roberts, 'Extremism in Germany: sparrows or avalanche?', European Journal of Political Research, 25(4) (1994), pp. 461-482; Uwe Backes, 'Meaning and forms of extremism in past and present', Central European Political Studies Review, 9(4) (2007), pp. 242-262.

${ }^{11}$ Mair, op. cit., Ref. 6, p. 181.

${ }^{12}$ Michael Billig, 'The extreme right: continuities in anti-Semitic conspiracy theory in post-war Europe', in Roger Eatwell and Noel O'Sullivan (Eds) The Nature of the Right: European and American Politics and Political Thought since 1789 (London: Pinter, 1989), p. 146.

${ }^{13}$ Cas Mudde, Populist Radical Right Parties in Europe (New York: Cambridge University Press, 2007), p. 13.

${ }^{14}$ An example that uses CMP data is Airo Hino, New Challenger Parties in Western Europe: A Comparative Analysis (Abingdon: Routledge, 2012). Studies that employ expert judgement data include: Marcel Lubbers, Mérove Gijsberts and Peer Scheepers, 'Extreme Right-Wing Voting in Western Europe', European Journal of Political Research, 41(3) (2002), pp. 345-378; Pippa Norris, Radical Right: Voters and Parties in the Electoral Market (New York: Cambridge University Press, 2005); Joost van Spanje, 'The wrong and the right: a comparative analysis of "anti-immigration" and "far right" parties', Government and Opposition, 46(3) (2011), pp. 293-320.

${ }^{15}$ Giovanni Sartori, 'Concept misformation in comparative politics', American Political Science Review, 64(4) (1970), p. 1038.

${ }^{16}$ Sartori, 'Guidelines', op. cit., Ref. 5, p. 79.

${ }^{17}$ Giovanni Sartori, 'The tower of Babel', in Giovanni Sartori, Fred W. Riggs and Henry Teune (Eds) Tower of Babel: On the Definition and Analysis of Concepts in the Social Sciences (International Studies, Occasional Paper no. 6, Pittsburgh PA: University of Pittsburgh, 1975), pp. 34-35.

${ }^{18}$ Mair, op. cit., Ref. 6, pp. 190-191.

19 David Collier and James E. Mahon Jr., "Conceptual "stretching" revisited: adapting categories in comparative analysis', American Political Science Review, 87(4) (1993), p. 845.

${ }^{20}$ Collier and Mahon, ibid.

${ }^{21}$ Sartori, 'The tower of Babel', op. cit., Ref. 17, p. 35.

${ }^{22}$ Paul Hainsworth, 'Introduction: the extreme right', in Paul Hainsworth (Ed.) The Politics of the Extreme Right: From the Margins to the Mainstream (London: Pinter, 2000), p. 4.

${ }^{23}$ David Collier and Robert Adcock, 'Democracy and dichotomies: a pragmatic approach to choices about concepts', Annual Review of Political Science, 2 (1999), p. 546.

${ }^{24}$ Mudde, 'Right-wing extremism analyzed', op. cit., Ref. 4; Roger Eatwell, 'The rebirth of the "extreme right" in Western Europe', Parliamentary Affairs, 53(3) (2000), pp. 407-425; Michael Minkenberg, 'The renewal of the radical right: between modernity and anti-modernity', Government and Opposition, 35(2) (2000), pp. 170-188; Elisabeth Carter, The Extreme in Western Europe: Success or Failure? (Manchester: Manchester University Press, 2005).

${ }^{25}$ Hans-Georg Betz, Radical Right-Wing Populism in Western Europe (Basingstoke: Macmillan, 1994); Paul Taggart, 'New populist parties in Western Europe', West European Politics, 18(1) (1995), pp. 34-51.

${ }^{26}$ Uwe Backes, 'L'extrême droite: les multiples facettes d'une catégorie d'analyse', in Pascal Perrineau (Ed.) Les croisés de la société fermée: l'Europe des extrêmes droites (La Tour d'Aigues: Editions de l'Aube, 2001), pp. 13-29; Carter, op cit., Ref. 24, p. 14.

${ }^{27}$ Peter Mair and Cas Mudde, 'The party family and its study', Annual Review of Political Science, 1 (1998), pp. 211229; Laurenz Ennser, 'The homogeneity of West European party families: the radical right in comparative perspective', Party Politics, 18(2) (2012), pp. 151-171. 
${ }^{28}$ Roger Eatwell, 'The nature of the Right, 2: the Right as a variety of "styles of thought"', in Eatwell and O'Sullivan (Eds), op. cit., Ref. 12, pp. 62-76; Piero Ignazi, Extreme Right Parties in Western Europe (Oxford: Oxford University Press, 2006).

${ }^{29}$ Norberto Bobbio, Left and Right: The Significance of a Political Distinction (Cambridge: Polity, 1996).

30 See, for example, Jan Rovny, 'Where do radical right parties stand? Position blurring in multidimensional competition', European Political Science Review, 5(1) (2013), pp. 1-26; though also see Herbert Kitschelt, The Radical Right in Western Europe: A Comparative Analysis (Ann Arbor: The University of Michigan Press, 1995); Herbert Kitschelt, 'Growth and persistence of the radical right in postindustrial democracies: advances and challenges in comparative research', West European Politics, 30(5) (2007), pp. 1176-1206.

${ }^{31}$ For example, de Lange has used Betz's (1994) definition on some occasions (see: Sarah L. de Lange, 'New alliances: why mainstream parties govern with radical right-wing populist parties', Political Studies, 60(4) (2012), pp. 899-918), while on others she has employed Mudde's (2007) - see: Tjitske Akkerman and Sarah L. de Lange, 'Radical right parties in office: incumbency records and the electoral cost of governing', Government and Opposition, 47(4) (2012), pp. 574-596. Similarly, Art uses a combination of Betz's and Mudde's definitions - see: David Art, Inside the Radical Right: The Development of Anti-Immigrant Parties in Western Europe (New York: Cambridge University Press, 2011).

${ }^{32}$ Minkenberg's 2000 article examines the radical right in the USA as well as elsewhere (see Minkenberg, 'The renewal of the radical right', op. cit., Ref. 24), Betz and Johnson explore the radical populist right in Australia and New Zealand (see Hans-Georg Betz and Carol Johnson, 'Against the current - Stemming the tide: the nostalgic ideology of the contemporary radical populist right', Journal of Political Ideologies, 9(3) (2004), pp. 311-327), and Mudde's 2007 book analyses the populist radical right in Eastern and Western Europe (see Mudde, Populist Radical Right Parties, op. cit., Ref. 13).

${ }^{33}$ In his 2003 article, Minkenberg examines social movements, smaller groups, and sociocultural milieus of the radical right. He argues that all these actors 'can be seen as components of an inter-related system of collective action, which centers on the ideological core of right-wing radicalism'. See: Michael Minkenberg, 'The West European radical right as a collective actor: modeling the impact of cultural and structural variables on party formation and movement mobilization', Comparative European Politics, 1(2) (2003), p. 153.

${ }^{34}$ Piero Ignazi, 'The silent counter-revolution: hypotheses on the emergence of extreme right-wing parties in Europe', European Journal of Political Research, 22(1) (1992), pp. 3-34; Betz, Radical Right-Wing Populism, op. cit., Ref. 25.

${ }^{35}$ Mudde, 'Right-wing extremism analyzed', op. cit., Ref. 4, p. 216.

${ }^{36}$ Reinhard Heinisch, 'Success in opposition - failure in government: explaining the performance of right-wing populist parties in public office', West European Politics, 26(3) (2003), p. 95.

${ }^{37}$ Nigel Copsey, Contemporary British Fascism: The British National Party and the Quest for Legitimacy (Basingstoke: Palgrave, 2nd Edition, 2008), p. 80.

${ }^{38}$ Mudde, Populist Radical Right Parties, op. cit., Ref. 13, p. 23.

39 Jens Rydgren, 'Is extreme-right populism contagious? Explaining the emergence of a new party family', European Journal of Political Research, 44(3) (2005), p. 433, note 1; Paul Hainsworth, The Extreme Right in Western Europe (Abingdon: Routledge, 2008), p. 11; Damir Skenderovic, The Radical Right in Switzerland: Continuity and Change, 1945-2000 (New York: Berghahn, 2009), p. 23.

${ }^{40}$ Mudde, 'Right-wing extremism analyzed', op. cit., Ref. 4, p. 209.

${ }^{41}$ Copsey, op. cit., Ref. 37, p. 80.

${ }^{42}$ Minkenberg, 'The West European radical right', op. cit., Ref. 33, p. 151.

${ }^{43}$ Eatwell, 'The rebirth of the "extreme right"', op. cit., Ref. 24, pp. 412-413.

${ }^{44}$ Mudde, Populist Radical Right Parties, op. cit., Ref. 13, p. 19.

${ }^{45}$ Terri E. Givens, Voting Radical Right in Western Europe (New York: Cambridge University Press, 2005), pp. 36-37.

${ }^{46}$ Martin, Schain, Aristide Zolberg and Patrick Hossay, 'The development of radical right parties in Western Europe', in Martin Schain, Aristide Zolberg and Patrick Hossay (Eds) Shadows over Europe: The Development and Impact of the Extreme Right in Western Europe (New York: Palgrave, 2002), pp. 3-17; Rydgren, op. cit., Ref. 39; Hainsworth, The Extreme Right in Western Europe, op. cit., Ref. 39; Skenderovic, op. cit., Ref. 39.

${ }^{47}$ Mudde, 'Right-wing extremism analyzed', op. cit., Ref. 4, p. 211.

${ }^{48}$ Mudde, ibid, p. 213.

${ }^{49}$ Heinisch, op. cit., Ref. 36, p. 95.

${ }^{50}$ Minkenberg, 'The renewal of the radical right', op. cit., Ref. 24, p. 180.

${ }^{51}$ Rydgren, op. cit., Ref. 39, p. 427.

${ }^{52}$ Betz and Johnson, op. cit., Ref. 32, p. 324.

53 Betz, Radical Right-Wing Populism, op. cit., Ref. 25; Hainsworth, The Extreme Right in Western Europe, op. cit., Ref. 39; Schain et al., op. cit., Ref. 46; Copsey, op. cit., Ref. 37; Skenderovic, op. cit., Ref. 39.

${ }^{54}$ Rydgren, op. cit., Ref. 39, p. 428.

${ }^{55}$ Minkenberg, 'The renewal of the radical right', op. cit., Ref. 24, p. 180. 
${ }^{56}$ Heinisch, op. cit., Ref. 36, p. 95.

${ }^{57}$ Givens, op. cit., Ref. 45, p. 20, p. 37.

${ }^{58}$ Mudde, Populist Radical Right Parties, op. cit., Ref. 13, p. 19.

${ }^{59}$ Carter, op cit., Ref. 24.

${ }^{60}$ Mudde, 'Right-wing extremism analyzed', op. cit., Ref. 4, p. 214.

${ }^{61}$ Schain et al., op. cit., Ref. 46; Givens, op. cit., Ref. 45.

62 Betz, Radical Right-Wing Populism, op. cit., Ref. 25, p. 4.

${ }^{63}$ Carter, op cit., Ref. 24, p. 17.

${ }^{64}$ Minkenberg, 'The West European radical right', op. cit., Ref. 33, p. 151; Betz and Johnson, op. cit., Ref. 32 , p. 312.

${ }^{65}$ Mudde, Populist Radical Right Parties, op. cit., Ref. 13, pp. 25-26.

${ }^{66}$ Hans-Georg Betz, 'Introduction', in Hans-Georg Betz and Stefan Immerfall (Eds) The New Politics of the Right: NeoPopulist Parties and Movements in Established Democracies (New York: St. Martin's Press, 1998), p. 3.

${ }^{67}$ Minkenberg, 'The West European radical right', op. cit., Ref. 33, p. 153.

${ }^{68}$ Mudde, Populist Radical Right Parties, op. cit., Ref. 13, p. 31, italics in original.

${ }^{69}$ Skenderovic, op. cit., Ref. 39, p. 15.

${ }^{70}$ Copsey, op. cit., Ref. 37, p. 80; Ignazi, 'The silent counter-revolution', op. cit., Ref. 34, p. 12.

71 Ignazi, 'The silent counter-revolution', op. cit., Ref. 34, p. 12; Giovanni Sartori, Parties and Party Systems: $A$ Framework for Analysis (Cambridge: Cambridge University Press, 1976), pp. 132-133.

72 Piero Ignazi, 'The extreme right: defining the object and assessing the causes', in Schain, Zolberg and Hossay (Eds), op. cit., Ref. 46, p. 26.

${ }^{73}$ Carter, op cit., Ref. 24, p. 22.

${ }^{74}$ Copsey, op. cit., Ref. 37, p. 80.

${ }^{75}$ Hainsworth, The Extreme Right in Western Europe, op. cit., Ref. 39, p. 11; Sartori, Parties and Party Systems, op. cit., Ref. 71, p. 133.

${ }^{76}$ Schain et al., op. cit., Ref. 46, p. 8.

${ }^{77}$ Minkenberg, 'The West European radical right', op. cit., Ref. 33, p. 152.

${ }^{78}$ Betz, Radical Right-Wing Populism, op. cit., Ref. 25, p. 4.

${ }^{79}$ Michael Minkenberg, 'The radical right in public office: agenda-setting and policy effects', West European Politics, 24(4) (2001), p. 3.

${ }^{80}$ Betz and Johnson, op. cit., Ref. 32, p. 312.

${ }^{81}$ Schain et al., op. cit., Ref. 46, p. 8.

${ }^{82}$ Cas Mudde, 'The war of words defining the extreme right party family', West European Politics, 19(2) (1996), p. 228.

${ }^{83}$ Sartori, 'Guidelines', op. cit., Ref. 5, p. 54.

${ }^{84}$ Mudde, 'Right-wing extremism analyzed', op. cit., Ref. 4.

${ }^{85}$ Sartori, 'Guidelines', op. cit., Ref. 5, p. 55.

${ }^{86}$ Mudde, 'Right-wing extremism analyzed', op. cit., Ref. 4, p. 218.

${ }^{87}$ Jørgen Goul Andersen and Tor Bjørklund, 'Radical right-wing populism in Scandinavia: from tax revolt to neoliberalism and xenophobia', in Hainsworth (Ed.) The Politics of the Extreme Right, op. cit., Ref. 22, p. 203.

${ }^{88}$ Mudde, Populist Radical Right Parties, op. cit., Ref. 13, pp. 21-23.

${ }^{89}$ Theodor W. Adorno, Else Frenkel-Brunswik, Daniel J. Levinson and R. Nevitt Sanford, The Authoritarian Personality (New York: Harper and Row, 1950).

90 Juan J. Linz, 'An authoritarian regime: Spain', in Erik Allardt and Yrjö Littunen (Eds) Cleavages, Ideologies and Party Systems (Helsinki: The Academic Bookstore, 1964), pp. 291-341.

${ }^{91}$ Linz, ibid., p. 297.

${ }^{92}$ Mudde, Populist Radical Right Parties, op. cit., Ref. 13, pp. 22-23.

${ }^{93}$ Adorno et al., The Authoritarian Personality, op. cit. Ref. 89. Bob Altemeyer, Right-wing Authoritarianism (Winnipeg: University of Manitoba Press, 1981); Bob Altemeyer, Enemies of Freedom: Understanding Right-wing Authoritarianism (San Francisco: Jossey-Bass, 1988).

${ }^{94}$ Friedrich Funke, 'The dimensionality of right-wing authoritarianism: lessons from the dilemma between theory and measurement', Political Psychology, 26(2) (2005), pp. 195-218; John Duckitt, Boris Bizumic, Stephen W. Krauss, and Edna Heled, 'A tripartite approach to right-wing authoritarianism: the authoritarian-conservatism-traditionalism model', Political Psychology, 31(5) (2010), pp. 685-715.

95 David Collier and Steven Levitsky, 'Democracy with adjectives: conceptual innovation in comparative research', World Politics, 49(3) (1997), p. 434.

${ }^{96}$ Sartori, The Theory of Democracy, op. cit., Ref. 7, p. 92; Larry Diamond and Leonardo Morlino, 'The quality of democracy: an overview', Journal of Democracy, 15(4) (2004), pp. 20-31. 
${ }^{97}$ Parties are unlikely to express opposition to the procedures and institutions of democracy without also rejecting the values of democracy. After all, it is their attitudes towards the values of democracy that shape their views on the procedures, and not the other way round.

98 John Gilmour, 'The extreme right in Spain: Blas Piñar and the spirit of the nationalist uprising', in Paul Hainsworth (Ed.) The Extreme Right in Europe and the USA (London: Pinter, 1992), pp. 220-221; Sheelagh Ellwood, 'The extreme right in Spain: a dying species?', in Luciano Cheles, Ronnie Ferguson and Michalina Vaughan (Eds) The Far Right in Western and Eastern Europe (London: Longman, 2nd Edition, 1995), p. 93.

99 Paul Furlong, 'The extreme right in Italy: old orders and dangerous novelties', Parliamentary Affairs, 45(3) (1992), pp. 345-356.

${ }^{100}$ Mudde, 'Right-wing extremism analyzed', op. cit., Ref. 4, pp. 211-213; Cas Mudde, The Ideology of the Extreme Right (Manchester: Manchester University Press, 2000), p. 151, p. 163.

${ }^{101}$ Mudde, 'Right-wing extremism analyzed', op. cit., Ref. 4, pp. 213-215; Carter, op cit., Ref. 24, p. 35.

102 Betz, Radical Right-Wing Populism, op. cit., Ref. 25, pp. 114-115; Skenderovic, op. cit., Ref. 39, pp. 111-113.

${ }^{103}$ Xavier Casals, 'Le national-populisme en Espagne: les raisons d'une absence', in Perrineau (Ed.), op. cit., Ref. 26, pp. 330-331.

${ }^{104}$ Eatwell, 'The rebirth of the "extreme right", op. cit., Ref. 24, p. 412.

${ }^{105}$ Minkenberg, 'The renewal of the radical right', op. cit., Ref. 24, p. 174; Mudde, Populist Radical Right Parties, op. cit., Ref. 13, p. 19.

${ }^{106}$ Rydgren, op. cit., Ref. 39, p. 433, note 1.

107 Givens, op. cit., Ref. 45, p. 20.

${ }^{108}$ Ignazi, 'The silent counter-revolution', op. cit., Ref. 34, p. 12; Betz, Radical Right-Wing Populism, op. cit., Ref. 25, p. 4; Heinisch, op. cit., Ref. 36.

${ }^{109}$ Hainsworth (Ed.) The Extreme Right in Europe and the USA, op. cit., Ref. 98; Betz and Immerfall (Eds), op. cit., Ref. 66; Hainsworth (Ed.), The Politics of the Extreme Right, op. cit., Ref. 22; Mudde, The Ideology of the Extreme Right, op. cit., Ref. 100; Ignazi, Extreme Right Parties in Western Europe, op. cit., Ref. 28; Hainsworth, The Extreme Right in Western Europe, op. cit., Ref. 39, pp. 77-81.

110 Michael Freeden, 'Is nationalism a distinct ideology?', Political Studies, 46(4) (1998), p. 753; Liah Greenfeld, 'Etymology, definitions, types', in Alexander J. Motyl (Ed.) Encyclopedia of Nationalism (Vol. 1) (San Diego CA: Academic Press, 2001), pp. 259-261.

111 Mudde, The Ideology of the Extreme Right, op. cit., Ref. 100, pp. 41-42.

112 Skenderovic, op. cit., Ref. 39, pp. 110-113.

113 Roger Griffin, 'The "post-Fascism" of the Alleanza Nazionale: a case study in ideological morphology', Journal of Political Ideologies, 1(2) (1996), pp. 123-145.

${ }^{114}$ Griffin, ibid., p. 132; Ignazi, Extreme Right Parties in Western Europe, op. cit., Ref. 28, pp. 47-51.

115 Ellwood, op. cit., Ref. 98, p. 103; Casals, op. cit., Ref. 103, p. 333; Thomas C. Davis, 'The Iberian peninsula and Greece: retreat from the radical right?', in Betz and Immerfall (Eds), op. cit., Ref. 66, p. 161; Panayote Elias Dimitras, 'Greece: the virtual absence of an extreme right', in Hainsworth (Ed.), The Extreme Right in Europe and the USA, op. cit., Ref. 98, pp. 265-266; Vassilis Kapetanyannis, 'Neo-Fascism in modern Greece', in Cheles, Ferguson and Vaughan (Eds), op. cit., Ref. 98, p. 136.

${ }^{116}$ Mudde, 'The war of words', op. cit., Ref. 82, p. 231; Backes, 'L'extrême droite', op. cit., Ref. 26, p. 20.

117 Paul Taggart, Populism (Buckingham: Open University Press, 2000); Margaret Canovan, 'Taking politics to the people: populism as the ideology of democracy', in Yves Mény and Yves Surel (Eds) Democracies and the Populist Challenge (Basingstoke: Palgrave, 2002), pp. 25-44; Cas Mudde, 'The populist Zeitgeist', Government and Opposition, 39(4) (2004), pp. 541-563. Michael Freeden, Ideologies and Political Theory: A Conceptual Approach (Oxford: Oxford University Press, 1996).

118 Mudde, ibid., p. 543.

${ }^{119}$ Yves Mény and Yves Surel, 'The constitutive ambiguity of populism', in Mény and Surel (Eds), op. cit., Ref. 117, pp. 1-21; Paul Taggart, 'Populism and representative politics in contemporary Europe', Journal of Political Ideologies, 9(3) (2004), pp. 269-288.

${ }^{120}$ Freeden, 'Is nationalism a distinct ideology?', op. cit., Ref. 110, p. 750.

121 Taggart, 'Populism and representative politics', op. cit., Ref 119; Catherine Fieschi, 'Introduction', Journal of Political Ideologies, 9(3) (2004), p. 238.

122 Ben Stanley, 'The thin ideology of populism', Journal of Political Ideologies, 13(1) (2008), pp. 99-100; Stijn van Kessel, 'The populist cat-dog: applying the concept of populism to contemporary European party systems', Journal of Political Ideologies, 19(1) (2014), p. 107.

${ }^{123}$ Pierre-André Taguieff, 'La rhétorique du national-populisme', Mots, 9 (1984), pp. 113-139.

${ }^{124}$ Mény and Surel, op. cit., Ref. 119, p. 4.

${ }^{125}$ Taggart, 'New populist parties', op. cit., Ref. 25; Mudde, Populist Radical Right Parties, op. cit., Ref. 13, pp. 49-56. 
${ }^{126}$ See Sartori, 'Guidelines', op. cit., Ref. 5; Gerring, 'What makes a concept good?', op. cit., Ref 9.

${ }^{127}$ Mudde, Populist Radical Right Parties, op. cit., Ref. 13, p. 23.

${ }^{128}$ Andrej Zaslove, 'The populist radical right: ideology, party families and core principles', Political Studies Review, 7(3) (2009), pp. 313-314.

${ }^{129}$ See Ennser, op. cit., Ref. 27, p. 155.

${ }^{130}$ Ignazi, Extreme Right Parties in Western Europe, op. cit., Ref. 28, pp. 225-229; Cas Mudde, 'Populist radical right parties in Europe: redux', Political Studies Review, 7(3) (2009), p. 331.

${ }^{131}$ Carter, op cit., Ref. 24, p. 17.

${ }^{132}$ Sartori, The Theory of Democracy, op. cit., Ref. 7, p. 24.

${ }^{133}$ Sartori, ibid., p. 368, p. 388.

${ }^{134}$ Sartori, 'Concept misformation', op. cit., Ref. 15.

${ }^{135}$ Ignazi, Extreme Right Parties in Western Europe, op. cit., Ref. 28, pp. 255-256.

${ }^{136}$ von Beyme, op. cit., Ref. 1. 